\title{
Penggunaan Media Belajar untuk Meningkatkan Pemahaman Bahaya Asap Rokok Pada Siswa Sekolah Dasar
}

\author{
Muhamad Syarifudin*, Rian Vebrianto** \\ * Program Magister Pendidikan Guru Madrasah Ibtidaiyah, Universitas Islam Negeri Sultan Syarif Kasim Riau \\ ** Program Magister Pendidikan Guru Madrasah Ibtidaiyah, Universitas Islam Negeri Sultan Syarif Kasim Riau
}

\section{INFO ARTIKEL}

\section{Riwayat Artikel:}

Diterima: $13-12-2019$

Disetujui: $16-12-2019$

\section{Kata kunci:}

Media belajar

Asap rokok

Efektifitas

\begin{abstract}
ABSTRAK
Abstract: This study aims to determine the effectiveness of learning media to increase students' understanding of the dangers of cigarette smoke. The research method used was experiment method using a questionnaire distributed to 25 respondents in grade V SDN 020 Sekijang Tapung Hilir. Data were analyzed using the SPSS method. From research conducted shows the use of media provides many benefits to students' understanding of the dangers of cigarette smoke. This can be seen from the average value obtained indicating that respondents generally answered yes or agreed to the statement given. The use of media can increase students' motivation to learn, and give high awareness to students about the dangers of cigarette smoke.
\end{abstract}

\begin{abstract}
Abstrak: Penelitian ini bertujuan untuk mengetahui efektifitas penggunaan media belajar untuk meningkatkatkan pemahaman siswa terhadap bahaya asap rokok. Metode penelitian yang digunakan adalah metode eksperimen menggunakan angket yang dibagikan kepada 25 responden siswa kelas V SDN 020 Sekijang Tapung Hilir. Data dianalisis menggunakan SPSS. Dari penelitian yang dilakukan menunjukkan penggunaan media memberikan banyak manfaat terhadap pemahaman siswa mengenai bahayanya asap rokok. Hal ini dapat dilihat dari nilai rata-rata yang diperoleh menunjukkan bahwa responden secara umum menjawab iya atau setuju akan pernyataan yang diberikan. Penggunaan media mampu meningkatkan motivasi peserta didik untuk belajar dan memberikan kesadaran yang tinggi kepada siswa tentang bahayanya asap rokok.
\end{abstract}

\section{Alamat Korespondensi:}

Muhamad Syarifudin

Program Magister Pendidikan Guru Madrasah Ibtidaiyah

Universitas Islam Negeri Sultan Syarif Kasim Riau

Pekanbaru

E-mail: muhamadsyarifudin8228@gmail.com

\section{LATAR BELAKANG}

Saat ini kebiasaan merokok sudah menjadi kebiasaan yang tidak asing lagi bagi masyarakat Indonesia. Layaknya kebutuhan makan, kebutuhan akan rokok juga menjadi sangat penting bagi sebagian besar masyarakat. Meskipun sosialisasi, kampanye hingga iklan anti rokok sudah disebarluaskan kepada masyarakat baik menggunakan media televisi hingga papan iklan berukuran besar disepanjang jalan tentang bahaya rokok, hingga pada setiap bungkus rokok juga terdapat peringatan bahaya rokok yang dapat menyebabkan kanker, serangan jantung hingga impotensi, namun hal ini tidak membuat masyarakat menjadi takut dan berhenti merokok, bahkan saat ini jumlah perokok menjadi semakin bertambah, bukan hanya orang dewasa, namun remaja hingga anak-anak sudah mulai mencoba merokok bahkan banyak diantaranya menjadikan rokok seperti kebutuhan.

Rokok adalah salah satu hasil olahan tembakau. Tembakau adalah tanaman dengan daun lebar yang berasal dari daerah Amerika Utara dan Amerika Selatan. Daun dari pohon ini sering digunakan sebagai bahan baku rokok. Rokok dibuat dengan bahan utama daun tembakau yang dikeringkan yang dapat mengandung $1 \%-3 \%$ senyawa nikotin. Bila rokok dinyalakan dan asapnya dihisap maka nikotin dalam darah meningkat sekitar $40-50 \mathrm{mg} / \mathrm{ml}$ darah (Nadia, 2016).

Banyak faktor yang berperan dalam peningkatan jumlah perokok remaja bahkan hingga anak-anak, diantaranya harga rokok yang murah; adanya gengsi dianggap tidak keren jika tidak merokok, adanya anggota keluarga atau bahkan orang tua yang juga merokok (Badan POM, 2016 ).

Ada beberapa fakta yang perlu kita ketahui tentang bahaya merokok. Ketika rokok dinyalakan, tembakau terbakar dan mengeluarkan asap, lebih dari 4000 bahan kimia terdapat di dalamnya. Ratusan diantaranya zat beracun dan sekitar 70 


\section{Instructional Development Journal (IDJ), Vol. 2, No. 2, Desember 2019, Hal. $71-75$}

bahan di dalamnya bersifat kanker (PMI, 2017). Bahan kimia yang terkandung dalam asap rokok diantaranya adalah nikotin, tar, gas, karbon monoksida, nitrogen oksida, hidrogen sianida, ammonia, akrolein, benzene, dan etanol. Ketika merokok, kandungan tar di dalam rokok akan ikut terhisap. Suatu fenomena yang jelas sekali bahwa organ pertama yang terkontaminasi oleh asap rokok dalam tubuh seseorang adalah saluran pernafasan dan paru-paru. Asap rokok dengan senyawa aktif senyawa tar dan nikotin, akan mengalami reaksi-reaksi yang bermula dari masuknya asap rokok dalam alveolus paru-paru dan memberikan pengaruh negatif pada gelembung paru-paru (Nadia, 2016). Zat ini akan mengendap di paruparu dan berdampak negatif pada kinerja rambut kecil yang melapisi paru-paru (Kemenkes, 2019).

Penelitian tentang bahaya rokok sudah banyak dilakukan. Angka kematian yang disebabkan oleh rokok akan terus meningkat. Pada tahun 2030 diperkirakan tembakau akan menjadi penyebab terbesar kematian diseluruh dunia, yang dapat mengakibatkan kematian satu diantara enam orang dewasa atau 10 juta kematian pertahun. Merokok dapat mengakibatkan penyakit serta kecacatan yang fatal, dan bila dibandingkan dengan perilaku berisiko lainnya, risiko kematian dini akibat merokok adalah luar biasa tingginya. Separo dari perokok jangka panjang pada akhirnya akan meninggal karena tembakau, dan di antara mereka, separonya akan mati dalam usia yang masih produktif, menyia-nyiakan 20-25 tahun sisa hidupnya. Penyakit yang berhubungan dengan rokok telah terdokumentasikan dengan baik, termasuk kanker paru-paru dan organ lainnya, penyakit jantung ischemic dan penyakit yang berhubungan dengan peredaran darah, penyakit pernapasan sepertiemfisema (emphisema). Di daerah-daerah dimana TBC berkembang, risiko terkena TBC bagi para perokok lebih besar dibandingkan mereka yang tidak merokok.

Merokok juga mempengaruhi kesehatan orang yang tidak merokok. Bayi-bayi dari ibu perokok lahir dengan berat badan yang rendah, menghadapi risiko tinggi terjangkit penyakit pernapasan, dan menghadapi risiko "sindrom bayi meninggal secara mendadak" (sudden death syndrome) yang lebih tinggi dibandingkan dengan bayi-bayi yang lahir dari ibu bukan perokok. Orang dewasa bukan perokok menghadapi risiko kecil, tetapi risiko untuk mendapat penyakit dan kecacatan yang fatal terus meningkat karena berhadapan dengan orang lain yang merokok.

Namun kenyataan ini seakan tidak mempunyai pengaruh terhadap para perokok aktif, mereka seakan tutup mata terhadap dampak membahayakan asap rokok ini. Bukan tidak ada peran pemerintah untuk mengurangi konsumsi rokok dari masyarakat, hanya saja kepedulian dan pemahaman perokok yang seperti acuh tak acuh yang menyebabkan program sosialisasi, kampanye hingga berbagai iklan hanya dianggap angin lalu.

Kebanyakan perokok aktif adalah mereka yang sudah mulai merokok dari usia remaja bahkan anak-anak sudah mulai mencoba merokok. Hal ini perlu mendapatkan perhatian khusus terutama dalam bidang pendidikan untuk dapat memberikan pemahaman sedini mungkin kepada anak-anak tentang bahaya asap rokok bagi kesehatan. Untuk dapat melihat secara langsung dampak asap rokok terhadap kesehatan diperlukan sarana belajar berupa media pembelajaran.

Media belajar merupakan alat bantu dalam proses pembelajaran yang dapat memudahkan pemahaman peserta didik. Media belajar dipersiapkan oleh guru sebelum masuk kelas. Media pembelajaran merupakan unsur yang penting dalam proses pembelajaran. Media pembelajaran merupakan sumber belajar yang dapat membantu guru dalam memperkaya wawasan siswa, dengan berbagai jenis media pembelajaran oleh guru maka dapat menjadi bahan dalam memberikan ilmu pengetahuan kepada siswa. Pemakaian media pembelajaran dapat menumbuhkan minat siswa untuk belajar hal baru dalam materi pembelajaran yang disampaikan oleh guru sehingga dapat dengan mudah dipahami. Media pembelajaran yang menarik bagi siswa dapat menjadi rangsangan bagi siswa dalam proses pembelajaran (Nurrita, 2018).

Dengan menggunakan media pembelajaran yang tepat dan menarik, pemahaman siswa akan menjadi lebih meningkat sehingga mampu meningkatkan tujuan pendidikan. Oleh sebab itu, guru mempunyai peran yang sangat penting untuk aktif dalam mengembangkan media belajar yang menarik dan interaktif. Penggunaan media pembelajaran mengenai dampak bahaya asap rokok diharapkan mampu memberikan kesadaran dan pemahaman kepada anak-anak mengenai sangat berbahaya nya asap rokok terhadap kesehatan terutama paru-paru.

\section{METODE}

Penelitian ini dilakukan di kelas V (lima) SDN 020 Sekijang Kec. Tapung Hilir Kabupaten Kampar. Dengan jumlah peserta didik yang terlibat dalam penelitian ini adalah sebanyak 25 orang. Pendekatan yang digunakan adalah pendekatan kuantitatif. Pendekatan kuantitatif penelitian adalah pendekatan yang menggunakan perhitungan angka atau kuantitas. Jenis penelitian ini adalah penelitian eksperimen. Penelitian ini menggunakan satu kelas eksperimen yang menggunakan media belajar dampak asap rokok terhadap paru-paru. Pemahaman siswa mengenai dampak bahaya rokok menggunakan media pembelajaran dinilai dengan metode quisioner berupa angket kepada siswa. Teknik pengumpulan data terhadap quisioner dianalisis menggunakan SPSS.

\section{HASIL}

Dari quisioner yang dibagikan kepada 25 responden dikalangan siswa kelas V SDN 020 Sekijang mengenai beberapa hal diantaranya penggunaan media belajar dampak asap rokok bagi kesehatan, metode mengajar guru, motivasi dan efektifitas penggunaan media belajar. Hasil quisioner ditampilkan pada Tabel berikut.

\section{Media Belajar}

Dari hasil quisioner mengenai penggunaan media belajar mengenai dampak asap rokok terhadap paru-paru didapatkan hasil sebagai berikut : 
Tabel 1. Nilai Rata-Rata Quisioner Media Pembelajaran yang digunakan

\begin{tabular}{clcc}
\hline No & \multicolumn{1}{c}{ Pertanyaan } & $\begin{array}{c}\text { Nilai Rata-Rata } \\
\text { Hasil Quisioner }\end{array}$ & Keterangan \\
\hline 1. & $\begin{array}{l}\text { Saya lebih mudah memahami pelajaran tentang dampak asap } \\
\text { rokok setelah guru menggunakan media pembelajaran }\end{array}$ & 2,76 & Iya \\
2. $\begin{array}{l}\text { Saya merasa bosan jika kegiatan belajar mengajar tidak } \\
\text { menggunakan media pembelajaran }\end{array}$ & 1,96 & Tidak \\
3. $\begin{array}{l}\text { Media tentang dampak asap rokok terhadap paru-paru mudah } \\
\text { dipraktekkan }\end{array}$ & 2,84 & Iya \\
4. $\quad \begin{array}{c}\text { Media yang digunakan kurang menarik } \\
\text { 5. } \quad \begin{array}{l}\text { Dengan menggunakan media pelajaran saya dapat melihat jelas } \\
\text { paru-paru akan menjadi rusak jika sering terkena asap rokok }\end{array}\end{array}$ & 2,16 & Tidak \\
\hline
\end{tabular}

\section{Metode Mengajar Guru}

Hasil quisioner mengenai tanggapan 25 responden siswa kelas V SDN 020 Sekijang terhadap metode mengajar guru ditampilkan dalam Tabel 2.

Tabel 2. Hasil Rata-rata Quisioner Metode Mengajar Guru

\begin{tabular}{clcc}
\hline No & \multicolumn{1}{c}{ Pertanyaan } & $\begin{array}{c}\text { Nilai Rata-Rata } \\
\text { Hasil Quisioner }\end{array}$ & Keterangan \\
\hline 1. & Guru menguasai materi pelajaran yang disampaikan & 2,88 & Iya \\
2. & $\begin{array}{l}\text { Guru menyampaikan materi pelajaran disertai dengan contoh- } \\
\text { contoh }\end{array}$ & 3,00 & Iya \\
3. & $\begin{array}{l}\text { Dalam menerangkan, guru menggunakan bahasa yang mudah } \\
\text { dipahami oleh siswa }\end{array}$ & 3,00 & Iya \\
4. & $\begin{array}{l}\text { Guru menyampaikan materi pelajaran dengan suara yang jelas } \\
\text { 5. Setiap ada pertanyaan dari siswa, guru akan menjelaskan sampai }\end{array}$ & 3,00 & Iya \\
& siswa itu jelas & 2,84 & Iya \\
\hline
\end{tabular}

Motivasi Peserta Didik

Untuk melihat peran media pelajaran terhadap motivasi belajar siswa dapat dilihat dari Tabel 3 berikut.

Tabel 3. Hasil Rata-rata Quisioner Motivasi Peserta Didik

\begin{tabular}{|c|c|c|c|}
\hline No & Pertanyaan & $\begin{array}{l}\text { Nilai Rata-Rata } \\
\text { Hasil Quisioner }\end{array}$ & Keterangan \\
\hline 1. & $\begin{array}{l}\text { Saya lebih rajin belajar karena media pembelajaran membuat } \\
\text { saya menyukai pelajaran ini }\end{array}$ & 2,88 & Iya \\
\hline 2. & $\begin{array}{l}\text { Saya merasa lebih terbantu memahami materi dampak asap } \\
\text { rokok setelah guru menggunakan media pelajaran }\end{array}$ & 3,00 & Iya \\
\hline 3. & $\begin{array}{l}\text { Dengan menggunakan media pembelajaran saya lebih } \\
\text { bersemangat untuk belajar }\end{array}$ & 2,84 & Iya \\
\hline 4. & $\begin{array}{l}\text { Saya merasa media pembelajaran tidak memiliki pengaruh } \\
\text { terhadap semangat belajar saya }\end{array}$ & 2,08 & Tidak \\
\hline 5. & $\begin{array}{l}\text { Saya menjadi lebih memiliki kesadaran tinggi bahwa asap rokok } \\
\text { memiliki dampak yang berbahaya bagi kesehatan }\end{array}$ & 2,88 & Iya \\
\hline
\end{tabular}

\section{Efektifitas Penggunaan Media}

Penggunaan media pembelajaran diharapkan mampu meningkatkan efektifitas belajar mengajar. Hasil rata-rata quisioner efektifitas penggunaan media belajar dampak asap rokok dapat dlihat pada Tabel 4 berikut.

Tabel 4. Hasil Rata-rata Quisioner Motivasi Peserta Didik Efektifitas Media

\begin{tabular}{clcc}
\hline No & \multicolumn{1}{c}{ Pertanyaan } & $\begin{array}{c}\text { Nilai Rata-Rata } \\
\text { Hasil Quisioner }\end{array}$ & Keterangan \\
\hline 1. & Saya tidak merasakan manfaat media pembelajaran & 2,04 & Tidak \\
2. & $\begin{array}{l}\text { Dengan menggunakan media pembelajaran, pembelajaran } \\
\text { menjadi lebih efektif dan efisien }\end{array}$ & 2,84 & Iya \\
3. & $\begin{array}{l}\text { Media pembelajaran membuat saya lebih fokus belajar dalam } \\
\text { membuat rancangan percobaan }\end{array}$ & 2,96 & Iya \\
4. & $\begin{array}{l}\text { Media pembelajaran membuat saya lebih bertanggung jawab } \\
\text { atas apa yang ditugaskan guru }\end{array}$ & 2,92 & Iya \\
5. $\begin{array}{l}\text { Saya lebih suka membaca teks daripada menggunakan media } \\
\text { pembelajaran }\end{array}$ & 1,96 & Tidak \\
\hline
\end{tabular}




\section{PEMBAHASAN \\ Media Belajar}

Berdasarkan Tabel 1 diatas dapat diketahui bahwa rata-rata siswa memberikan hasil positif terhadap penggunaan media mengenai dampak asap rokok ini. Pada pernyataan siswa lebih mudah memahami pelajaran tentang dampak asap rokok setelah guru menggunakan media pembelajaran didapatkan hasil rata-rata sebanyak 2.76 atau sekitar $80 \%$ siswa setuju terhadap pernyataan tersebut. Hal ini sesuai dengan hasil penelitian yang dilakukan oleh Saputro (2016) bahwa penggunaan media belajar komik islami dapat meningkatkan prestasi belajar siswa dan kemampuan berpikir kritis. Sesuai dengan manfaatnya, penggunaan media belajar bahan pengajaran akan lebih memperjelas materi pelajaran sehingga dapat lebih di pahami siswa, serta memungkinkan siswa menguasai tujuan pengajaran dengan baik (Nurrita, 2018).

Dari hasil quisioner, penggunaan media dampak asap rokok merupakan media yang menarik, mudah dipraktekkan sehingga siswa menjadi tidak bosan. Dengan metode pembelajaran bervariasi, tidak semata-semata hanya komunikasi verbal melalui penuturan kata-kata lisan pengajar, siswa tidak bosan, dan pengajar tidak kehabisan tenaga (Nurrita, 2018).

Dengan menggunakan media belajar dampak asap rokok, siswa menjadi lebih paham dan menyadari bahaya yang ditimbulkan akibat merokok secara langsung, bahwa tisu yang awalnya putih, berubah menjadi kuning akibat asap rokok. Hal inilah yang akan terjadi pada paru-paru jika sering menghirup asap rokok. Sehingga diharapkan siswa menjadi lebih waspada dan tidak tertarik bahkan takut untuk merokok.

\section{Metode Mengajar Guru}

Dari Tabel 2 diatas dapat disimpulkan bahwa siswa memberikan penilaian positif terhadap metode yang dilakukan guru dalam mengajar. Guru menguasai materi pelajaran, penyampaian materi disertai contoh untuk lebih memudahkan pemahaman siswa, menggunakan bahasa yang mudah dipahami siswa, menggunakan suara yang jelas, serta mengulangi penjelasan disaat siswa belum mengerti.

Seorang guru membutuhkan kompetensi yang baik sehingga dapat mengembangkan dan menyajikan materi pelajaran yang aktual dengan menggunakan berbagai pendekatan, metoda, dan teknologi pembelajaran terkini di sekolah, yang akan berdampak positif bagi peningkatan proses pembelajaran itu sendiri, serta dapat menghasilkan mutu pendidikan yang tinggi pula. Kompetensi guru yaitu kecakapan, kemampuan dan keterampilan yang dimiliki oleh seseorang yang bertugas mendidik siswa agar mempunyai kepribadian yang luhur dan mulia sebagaimana tujuan dari pendidikan (Trianto, 2010 dalam Permana, 2017). Menurut Mulyasa (2007) dalam Permana (2017) kompetensi guru merupakan perpaduan antara kemampuan personal, keilmuan, teknologi, sosial, dan spiritual yang secara menyeluruh membentuk kompetensi standar profesi guru.

Sedangkan kompetensi yang wajib dimiliki guru berdasarkan pasal 8 dijelaskan dalam pasal 10 (1) yaitu guru wajib memiliki kompetensi pedagogik, kompetensi kepribadian, kompetensi sosial, dan kompetensi profesional yang diperoleh melalui pendidikan profesi. Kompetensi pedagogik adalah kemampuan mengelola pembelajaran peserta didik. Kompetensi pedagogik guru penting untuk ditingkatkan, karena kompetensi pedagogik guru akan meningkatkan kompetensi profesionalisme guru dalam mengajar, karena dengan memiliki kompetensi pedagogik, maka guru memiliki kemampuan dalam mengatur materi pembelajaran yang akan disampaikan dengan baik kepada murid-muridnya dengan berbagai teknik (Rahman, 2014 dalam Tyagita, 2018). Kompetensi kepribadian adalah kemampuan kepribadian yang mantap, berakhlak mulia, arif, dan berwibawa serta menjadi teladan peserta didik. Kompetensi sosial adalah kemampuan guru untuk berkomunikasi dan berinteraksi secara efektif dan efisien dengan peserta didik, sesama guru, orangtua/wali peserta didik, dan masyarakat sekitar (UU No 14 Tahun 2005). Kompetensi sosial: merupakan kemampuan guru sebagai bagian dari masyarakat yang sekurang-kurangnya meliputi kompetensi untuk: berkomunikasi lisan, tulis, dan/atau isyarat secara santun; menggunakan teknologi komunikasi dan informasi secara fungsional; bergaul secara efektif dengan peserta didik, sesame pendidik, tenaga kependidikan, pimpinan satuan pendidikan, orang tua atau wali peserta didik; bergaul secara santun dengan masyarakat sekitar dengan mengindahkan norma serta sistem nilai yang berlaku; menerapkan prinsip persaudaraan sejati dan semangat kebersamaan (Azwi, Nurma dan Rizkiyatul, 2017). Kompetensi profesional adalah kemampuan penguasaan materi pelajaran secara luas dan mendalam.

\section{Motivasi Peserta Didik}

Dari Tabel 3 diatas dapat dilihat bahwa penggunaan media dampak asap rokok mampu memberikan semangat belajar yang lebih tinggi, serta siswa menjadi lebih memiliki kesadaran tinggi bahwa asap rokok memiliki dampak yang berbahaya bagi kesehatan. Hal ini juga sesuai dengan penelitian yang dilakukan oleh Putri (2017) yang melakukan penelitian tentang "Pengaruh Media Pembelajaran Terhadap Motivasi Belajar Bahasa Arab Siswa Madrasah Tsanawiyah". Dari hasil penelitian didapatkan hasil bahwa penggunaan media belajar mempunyai pengaruh yang signifikan terhadap motivasi belajar, jika guru menggunakan media belajar secara maksimal, maka motivasi belajarpun akan tinggi. Sebaliknya jika dalam penggunaan media minim, maka motivasinya akan rendah. Motivasi belajar tidak dapat muncul begitu saja dalam diri siswa. Saat pembelajaran menggunakan media dapat memancing siswa untuk menjadi semangat dan termotivasi, sehingga mempermudah seseorang untuk memahami pembelajaran tersebut. Motivasi belajar juga merupakan hasrat untuk belajar dari seorang siswa. Siswa dapat belajar secara lebih efisien apabila adanya media pembelajaran sehingga ia berusaha untuk belajar secara maksimal, artinya siswa termotivasi dari dalam dirinya sendiri untuk belajar (Puspitasari, Puspita dan Woro, 2018). 


\section{Efektifitas Penggunaan Media}

Berdasarkan Tabel 4 diatas dapat disimpulkan bahwa penggunaan media belajar dampak asap rokok dapat membuat pelajaran menjadi lebih efisien dan efektif, siswa menjadi lebih fokus dan bertanggung jawab dalam mengerjakan tugas yang diberikan guru. Keefektifan penggunaan media dapat terlihat dari semangat dan antusias siswa dalam mengikuti pembelajaran dan hasil pemahaman siswa terhadap materi dampak asap rokok terhadap paru-paru ini. Hal ini juga sesuai dengan hasil penelitian yang dilakukan oleh Mardiah dan Said (2018) mengenai efektifitas media pembelajaran media kartu dan media TTS (Teka Teki Silang terhadap hasil belajar siswa kimia siswa SMA negeri 16 Banda Aceh. Dari hasil penelitian dapat disimpulkan bahwa penggunaan media belajar dapat meningkatkan keefektifan belajar dengan dibuktikan semangat belajar siswa dalam mengisi dan mencari jawaban teka teki silang (Mardhiah dan Said, 2018). Sehingga dengan adanya penggunaan media belajar dapat membantu guru dalam menyampaikan pesan-pesan materi pelajaran kepada siswa secara lebih mudah. Siswa akan lebih mudah memahami materi yang disampaikan dengan menggunakan media belajar. Sehingga media belajar merupakan sesuatu yang sangat penting untuk menunjang keberhasilan pembelajaran.

\section{SIMPULAN DAN SARAN}

\section{Simpulan}

Dari hasil penelitian ini dapat disimpulkan bahwa: 1) media pembelajaran merupakan alat atau perangkat untuk menyampaikan pesan-pesan materi kepada siswa; 2) media belajar mampu membuat siswa menjadi lebih memahami dan memiliki kesadaran yang tinggi mengenai dampak asap rokok terhadap kesehatan; 3) media belajar dapat meningkatkan motivasi belajar siswa; dan media belajar terbukti efektif untuk digunakan dalam proses belajar mengajar.

\section{Saran}

Dari penelitian ini, penulis menyarankan dalam kegiatan pembelajaran agar dapat menggunakan media pembelajaran untuk memicu semangat dan konsentrasi peserta didik serta penulis menyarankan untuk melakukan pengembangan media belajar yang lebih inovatif dan kreatif.

\section{DAFTAR RUJUKAN}

Azwi, N.M., Nurma, Rizkiyatul, F. 2017. Analisis Undang-Undang Guru dan Dosen. Fakultas Tarbiyah Institut Ilmu AlQur'an (IIQ) Jakarta.

Kementerian Kesehatan Republik Indonesia. 2019. Berhenti Merokok. Pasti Bisa. www. Kemenkes.go.id

Mardhiah, A. Dan Said A.A. 2018. Efektifitas Media Pembelajaran Terhadap Hasil Belajar Kimia Siswa SMA Negeri 16 Banda Aceh. Lantanida Journal, Vol. 6 No. 1 (2018).

Nadia, L. 2016. Pengaruh Negatif Merokok Terhadap Kesehatan dan Kesadaran Masyarakat Urban. Peran Matematika, Sains dan Teknologi dalam Mendukung Gaya Hidup Perkotaan (Urban Lifestyle) yang Berkualitas. Universitas Terbuka. Tangerang Selatan.

Nurrita, T. 2018. Pengembangan Media Pembelajaran Untuk Meningkatkan Hasil Belajar Siswa. Jurnal Misykat Volume 03 Nomor 01, Juni 2018.

Permana, N.S. 2017. Peningkatan Mutu Tenaga Pendidik Dengan Kompetensi dan Sertifikasi Guru. Studia Didaktika: Jurnal Ilmiah Bidang Pendidikan Vol. 11, No. 1, 2017.

PMI.com. Dampak Merokok Terhadap Kesehatan.

https://www.pmi.com/resources/docs/defaultsource/market pages smoke and health/health-effects-ofsmoking_id.pdf?.sfvrsn=4028b7b5_4

Putri, W.N. 2017. Pengaruh Media Pembelajaran Terhadap Motivasi Belajar Bahasa Arab Siswa Madrasah Tsanawiyah. Lisania : Journal of Arabic and Litrature Vol.1, No.1, 2017, pp 1-16.

Puspitasari, P., Puspita, S.J.P. dan Woro, W. 2018. Pengaruh Penggunaan Media Pembelajaran Terhadap Motivasi Belajar Mahasiswa IKIP Siliwangi. Parole : Jurnal Pendidikan Bahasa dan Sastra Indonesia, Volume 1 Nomor 2, Maret 2018.

Saputra, A.D. 2016. Implementasi Media Pembelajaran Komik Islam untuk Meningkatkan Prestasi Belajar dalam Berpikir Kritis Siswa Di Sekolah. Jurnal Ulul Albab Volume 17 Nomor 1, Tahun 2016.

Sentra Informasi Keracunan Nasional Pusat Informasi Obat dan Makanan, Badan POM. 2016. Remaja, Tembakau dan Rokok. Jakarta.

Tyagita, B.P.A. 2018. Strategi Peningkatan Kompetensi Pedagogik Guru Untuk Meningkatkan Mutu Sekolah. Kelola : Jurnal Manajemen Pendidikan, Vol. 5, No. 2, Juli-Desember 2018.

Undang-Undang Nomor 14 Tahun 2005 tentang Guru dan Dosen. 